\title{
PENGGUNAAN MEDIA BERITA TV UNTUK MENINGKATKAN BERPIKIR KRITIS SISWA DALAM PEMBELAJARAN MENULIS TEKS EKSPLANASI PADA SISWA KELAS XI SMK ICB CINTA WISATA (Studi Eksperimen di SMK ICB Cinta Wisata Bandung)
}

\author{
Desti Kusmayanti \\ SMK ICB Cinta Wisata Bandung \\ Email: dkusmayanti@gmail.com
}

\begin{abstract}
Abstrak
Penelitian ini bertujuan untuk mengetahui keterlaksanaan penggunaan media berita TV pada materi menulis teks eksplanasi dan mengetahui peningkatan kemampuan berpikir kritis siswa. Metode penelitian yang digunakan adalah kuasi eksperimen dengan desain one group pretest posttest. Penelitian ini dilaksanakan di kelas XI PN 1 SMK ICB Cinta Wisata Bandung. Instrumen yang digunakan dalam penelitian ini adalah tes yang berupa lembar soal serta lembar observasi sebagai pendukung keterlaksanaan pembelajaran menggunakan media berita TV dalam pembelajaran menulis teks eksplanasi dan keterampilan berpikir kritis. Instrumen tersebut dikategorikan valid dan realiabel setelah dilakukan analisis oleh Expert Judgment. Hasil penelitian menunjukkan aktivitas siswa mengalami peningkatan dengan nilai rata-rata pretes sebesar 43,2 dan rata-rata postes sebesar 81,3 . Peningkatan keterampilan berpikir kritis siswa setelah digunakannya media berita TV sesuai dengan hasil uji hipotesis gain yaitu nilai probalitas atau Sig. (2-tailed) $0,00<0,05$. Besarnya peningkatan keterampilan berpikir kritis ditunjukkan oleh hasil uji hipotesis yang menyatakan adanya perbedaan data hasil pretest dan postest sehingga ada peningkatan pembelajran dengan melihat rata-rata dari setiap kegiatan. Dengan demikian media berita TV dapat dijadikan alternatif media pembelajaran yang digunakan untuk meningkatkan keterampilan berpikir kritis siswa padapembelajaran menulis teks eksplanasi.
\end{abstract}

Kata kunci: media berita TV, berpikir kritis, dan menulis teks eksplanasi

\begin{abstract}
The objectives of this research are to know the implementation of TV news media in writing explanation text and to know the improvement of the students in thinking critically. The research method used quasi experimental design with one group pretest and post test. This research was conducted at XI PN 1 ICB Cinta Wisata Bandung. The instruments used test and observation. The instruments are categorized valid and reliable after conducting analysis by expert judgment. The result of the research showed that there was an improvement from the mean of pre test 43.2 to the mean of post test 81.3. The improvement of students' critical thinking after using TV news media was suitable with the result of hypothesis gain, probability score or sig ( 2 tailed) $0.00<0.05$. The improvement of the students' critical thinking was showed by the result of hypothesis test that there was the difference of data between pre test and post test in every activity. Therefore, TV news media can be one of alternatives learning media that can be used to improve the students' critical thinking in writing explanation text.
\end{abstract}

Key words: TV news media, critical thinking, writing explanation text. 


\section{PENDAHULUAN}

Pada era globalisasi masyarakat sering mengalami peningkatan baik secara teknologi maupun pendidikan. Demi upaya pembaharuan dalam dunia pendidikan, media sangat penting guna mencapai tujuan pembelajaran yang menyenangkan. Arsyad mengungkapkan (2015: 25), media yang sering diganti dengan kata mediator adalah penyebab atau alat bantu yang turut campur tangan dalam dua pihak dan mendamaikannya. Jadi, secara bahasa media pembelajaran berarti pengantar pesan dari pengirim kepada penerima pesan dalam proses pembelajaran.

Media pembelajaran dapat dioptimalkan, salah satunya untuk mengasah keterampilan berpikir siswa guna memunculkan pemahaman yang dibangun oleh siswa itu sendiri. Menurut Sadiman (2014:7) media hendaknya dapat dimanipulasi, dapat dilihat, didengar dan dibaca. Hal lain diungkapkan Daryanto (2010:7) media perlu diperhatikan oleh guru agar mereka dapat memilih media mana yang sesuai dengan kondisi dan kebutuhan. Oleh karena itu media pembelajaran harus dipilih dan dikemas dengan baik oleh guru, sehingga aspek kognitif akan menjadi lebih baik, karena media pembelajaran mempunyai keuntungan, seperti pembelajaran semakin terserap, menarik dan memberikan kemudahan dalam penyampaiannya.

\section{KAJIAN TEORETIS}

Media komunikasi telah mempengaruhi banyak perilaku dan kegiatan manusia dalam kehidupan sehari-hari termasuk terhadap dunia pendidikan. Salah satu media yang sangat berpengaruh adalah media televisi. Menurut Sutisno (1993:1), media televisi pada hakikatnya merupakan suatu sistem komunikasi yang menggunakan suatu rangkaian gambar elektronik yang dipancarkan secara cepat, berurutan dan diiringi unsur audio. Senada dengan hal tersebut Effendy (2002:21) mengungkapkan televisi adalah siaran yang merupakan media dari jaringan komunikasi dengan ciri-ciri yang dimiliki komunikasi massa, yaitu berlangsung satu arah, komunikatornya melembaga, pesannya bersifat umum, sasarannya menimbulkan keserempakan, dan komunikasinya bersifat heterogen. Oleh karena itu televisi merupakan salah satu alat penyampai informasi yang disampaikan melaluai audio visual dan berlangsung satu arah. Namun terkadang program tv lain yang tidak mendidik akan mempengaruhi perilaku negatif siswa, seperti kekerasan, penyimpangan etika serta adat istiadat.

Salah satu tayangan televisi yang menyampaikan infomasi secara faktual dan terpercaya adalah berita. Program tayangan ini, dirasa penting bagi keberlangsungan pendidikan. Menurut Chaer (2010:11) berita adalah suatu peristiwa atau kejadian di dalam masyarakat, lalu kejadian atau peristiwa itu diulangi dalam bentuk kata-kata yang disiarkan secara tertulis dalam media tulis (surat kabar, majalah, dll) atau dalam media suara (radio,dsb), atau juga dalam media suara dan gambar (televisi).

Fisher (2009:10) mengatakan, berpikir kritis adalah interpretasi dan evaluasi yang terampil dan aktif terhadap observasi dan komunikasi, informasi dan argumentasi. Ia mendefinisikan berpikir kritis sebagai proses aktif, karena ia melibatkan tanya jawab dan berpikir tentang pemikiran diri. Hal tersebut dapat didapatkan dari hasil pengamatan, pengalaman, akal sehat atau komunikasi. Menurut Fachruddin (2015:14) berpikir kritis adalah berpikir secara beralasan dan efektif dengan menekankan pembuatan tentang apa yang harus dipercayai atau dilakukan. Belajar untuk berpikir kritis berarti menggunakan proses-proses mental, seperti memperhatikan, mengkategorikan, seleksi, menilai dan memutuskan. 
Kemampuan berpikir kritis sangat diperlukan, mengingat bahwa dewasa ini ilmu pengetahuan dan teknologi berkembang sangat pesat, dan memungkinkan siapa saja bisa memperolah informasi secara cepat dan mudah dengan melimpah dari berbagai sumber dan tempat manapun di dunia. Menurut Molan (2012:12) membangun sikap kritis sebenarnya dimaksudkan untuk mengajak kita berpikir jernih. Paparan tersebut mengarahkan kita pengajar agar membangun siswa yang mampu berpikir kritis dalam mata pelajaran Bahasa Indonesia. Sulitnya melatih siswa berpikir jernih menjadi kendala bagi seorang guru, sebab akan menggangu hasil belajar. Sehubungan dengan hal tersebut, guru harus pintar membiasakan siswa untuk berpikir kritis. Melatih siswa dan membiasakan berpikir kritis akan mengasah kemampuan siswa dalam bidang komunikasi, baik secara lisan maupun tulisan. Berlatih merupakan suatu proses yang digunakan untuk memperoleh kemahiran atau kecakapan. Agar siswa lebih terampil dalam berpikir dan berkomunikasi, pendidik harus memilih pembelajaran yang bisa mengasah serta melatih pemikiran siswa guna meningkatkan daya berpikir kritis siswa.

Berdasarkan Kurikulum 2013 tingkat SMA/SMK, pada mata pelajaran Bahasa Indonesia kelas XI terdapat beberapa jenis teks yang akan dipelajari oleh siswa antara lain teks eksplanasi, teks ulasan, teks cerpen, dll. Salah satu pembelajaran yang dapat melatih berpikir siswa dalam ranah keterampilan pembelajaran Bahasa Indonesia adalah memproduksi teks eksplanasi, secara langsung harus menghasilkan suatu karya yang berupa tulisan. Menurut Tarigan (2008:3) menulis merupakan suatu keterampilan berbahasa yang dipergunakan untuk berkomunikasi secara tidak langsung, tidak secara tatap muka dengan orang lain. Menulis merupakan salah satu aspek komunikasi yang dapat menuangkan ide dan gagasan dengan terkonsep, sehingga pembaca akan lebih jelas memahami isi informasinya. Agar bisa menghasilkan gagasan, ide yang terkonsep maka siswa dituntut harus berpikir secara kritis.

Kegiatan menulis merupakan bagian yang tidak terpisahkan dari seluruh pembelajaran yang dialami oleh siswa di sekolah. Alwasilah (2010:48) menyatakan, bahwa siswa tidak ada keberanian untuk menulis karena takut salah dan ditertawakan orang. Di sinilah peran guru sangat diperlukan dalam kegiatan pembelajaran. Menurut Nurhadi (2004:191), bahwa tugas guru adalah melatih siswa membaca dan menulis sebanyak-banyaknya dan berdiskusi sebanyak-banyaknya. Dalam pembelajaran ini siswa dituntut bisa berdisukusi dan berlatih menulis teks eksplanasi.

Teks eksplanasi merupakan jenis teks yang berisi tentang pemaparan penjelasan mengenai proses terjadinya suatu peristiwa. Menurut Prihantini (2015:102) teks eksplanasi sering dipakai untuk karya ilmiah untuk menjelaskan tentang proses terciptanya sesuatu yang terjadi secara ilmiah. Eksplanasi bisa dikatakan lebih rumit daripada teks-teks lain karena merupakan gabungan dari berbagai jenis teks, seperti deskriptif, prosedur dan teks argumentasi, seperti eksposisi (Emilia 2011:127).

Melalui pembelajaran menulis teks eksplanasi, diharapkan siswa dapat berlatih dalam mengungkapkan pikirannya secara jernih, untuk menerangkan atau menjelaskan serangkaian proses dari suatu peristiwa atau fenomena alam yang diketahuinya secara benar berdasarkan sebab dan akibat. Dengan begitu kemampuan menulis siswa akan terlatih secara kritis dalam mencari pengetahuan dan fakta-fakta, walaupun dianggap lebih rumit dari teks lain.

Berdasarkan pengalaman di lapangan, kemampuan memproduksi teks sis- 
wa SMK ICB Cinta Wisata kelas XI masih rendah jika tidak ada media atau metode yang menarik. Hal ini disebabkan berbagai faktor antara lain, fasilitas kurang memadai, sumber daya siswa yang rendah secara kognitif, malas menulis, materi kurang menarik dan sulit memahami isi materi. Di samping itu, yang ditulis oleh siswa hanya berupa karangan yang direka-reka saja, sebab tidak ada media yang bisa memicu stimulus otak siswa agar mau berpikir kritis dan berpendapat secara logis. Teks ekplanasi dirasa sulit oleh mereka, sebab banyak struktur yang kurang dipahami. Selain itu siswa sulit menentukan gagasan karena kurang dan pahamnya informasi yang mereka terima. Dampak dari hal tersebut, tulisan siswa tidak sesuai dengan struktur dan ciri-ciri teks eksplanasi. Oleh karena itu, menulis teks eksplanasi dapat melatih berpikir kritis siswa dalam merumuskan masalah, menemukan sebab akibat dan pernyataan umum dalam sebuah teks, jika menggunakan media yang sesuai dan menarik bagi siswa.

\section{METODE PENELITIAN}

Penelitian ini akan menggunakan penelitian kuantitatif eksperimen. Penelitian dengan menggunakan percobaan atau eksperimen dimaksudkan untuk menyelidiki kemungkinan sebab akibat, dengan cara mengekspos satu atau lebih kelompok eksperimental dan satu atau lebih kondisi eksperimen. Desain penelitian eksperimen yang digunakan adalah penelitian quasi-experiment. Menurut Indrawan dan Yaniawati (2014:58 ) dalam penelitian ini dua kelompok diamati, dimana salah satu diberi perlakuan sedang yang satu tidak. Menurut Subana (2001:105) eksperimen ini merupakan perluasan dari rancangan pra uji (pretest) dan pasca uji (posttest) dari suatu kelompok.

Syamsudin dan Vismaya (2009:162) mengungkapkan dengan menggu- nakan rancangan ekperimen semu ini, kita mengontrol banyak variabel dan batasan dari jenis interpretasi yang akan kita lakukan untuk mengetahui sebab pengaruh pertautan dan membatasi kekuatan dari generalisali pernyataan kita. Hal lain diungkapkan Ruseffendi (1998:47) kuasi eksperimen ini tidak berbeda dengan desain kelompok pretes dan postes, jadi pada desain eksperimen ini ada pretes, perlakuan yang berbeda dan ada postes. Menurut (Sugiyono 2009:110) menyatakan bahwa, dalam eksperimen kuasi terdapat 3 jenis desain penelitian antara lain, one-shot chas study, one group pretestposttes, dan intact group comparasion. Dari ketiga jenis tersebut penulis memilih desain one group pretes-postes. Dalam desain ini kelompok yang digunakan untuk penelitian tidak dapat dipilih secara random. Sebelum diberi perlakuan, kelompok diberi satu kali pre-test. Setelah hasil pre-test diperoleh maka kelompok baru diberi treatment. Selanjutnya diberikan treatment yang dilakukan satu kali pascates. Desain penelitian ini hanya menggunakan satu kelompok saja, sehingga tidak memerlukan kelompok kontrol.

\section{HASIL DAN PEMBAHASAN}

\section{Analisis Peningkatan Kemampuan Berpikir Kritis Siswa dalam Pem- belajaran Menulis Teks Ekspla- nasi}

Analisis ini bertujuan untuk mengetahui kemampuan berpikir kritis siswa dalam pembelajaran menulis teks eksplanasi dengan menggunakan media berita TV pada kelas XI PN 1, berdasarkan hasil analisis diperoleh data sebagai berikut.

Berdasarkan tabel bahwa rata-rata pretetst siswa di kelas XI PN 1 yaitu sebesar 43,2 dengan jumlah sebesar 995 . Nilai terendah sebesar 34 dan nilai tertinggi sebesar 67. Data tersebut menunjukan jika prestasi belajar siswa masih rendah, sehingga perlunya peningkatan 
berpikiri kritis siswa dalam pemvelajaran menulis teks eksplanasi.

Dari hasil data posttest diperoleh jumlah sebesar 1866 dan hasil rata-rata siswa dengan nilai sebesar 81,3 . Nilai terendahnya sebesar 67 dan nilai tertinggi sebesar 89. Data pretes menunjukan nilai hasil rata-rata siswa sebesar 43,26 dengan jumlah sebesar 995. Hal tersebut menunjukan adanya peningkatan hasil belajar siswa.

\section{Uji Normalitas}

Berdasarkan pengolahan data diperoleh dari hasil uji normalitas yaitu berdistribusi normal. Dari data tersebut diperoleh skewness pretes sebesar 0,868 dan kurtosois pretest sebesar -0,296. Skewness posttest sebesar 0,296 dan kurtosois posttest sebesar $-0,570$, sehingga dapat disimpulkan bahwa data nilai kemampuan menulis teks eksplanasi siswa berdistriusi normal. Hasil tersebut diolah kembali untuk mengetahui hasil uji hipotesis dengan Paired Sample T-test.

\section{Uji Paired Sample T-test}

Untuk menguji hipotesis maka digunakan uji paired sample t-test. Nilai pretest diperoleh diperoleh rata-rata hasil belajar yakni 43,26, sedangkan untuk nilai posttest diperoleh rata-rata sebesar 81,35 . Jumlah responden atau siswa yang dijadikan sampel sebanyak 23 orang siswa. Untuk pretest diperoleh Std. Deviation 6,757 dan Std. Eror Mean 1,409. Untuk posttest Std. Deviation 6,386 dan Std. Eror Mean 1,332. Berdasarkan output bagian ketiga, diketahui bahwa nilai sig. (2-tailed) sebesar 0,00. Nilai sig tersebut menunjukan $0,00<0,05$. Apabila nilai probalitas atau Sig. (2-tailed) < 0,05 maka terdapat perbedaan yang signifikan antara hasil belajar pada data pretest dan posttest yang artinya adanya peningkatan data pretest dan posttest, sehingga hipotesis dapat diterima. a) Media berita TV Pada Pembelajaran Menulis Teks Eksplanasi

Pada hasil data yang diperoleh, bahwa media pembelajaran akan baik doigunakan guna menciptakan pembelajaran yang menyenangkan. Hal tersebut diketahui melalui penerapan media berita TV dalam pembelajaran menulis teks eksplanasi. Siswa menjadi aktif bertanya ketika diberika media audio visual. Media tersebut cocok digunakan untuk membuat pola pikir siswa menjadi lebih terbuka. Selain itu media ini sangat mudah didapat oleh guru. Hal tersebut sependapat dengan Arsyad (2015:141) media audio visual merupakan bentuk media pembelajaran yang murah dan terjangkau.

Berdasarkan data dan hasil pengolahan data, bahwa media berita TV baik digunakan untuk meningkatkan berpikir kritis siswa. Siswa menjadi lebih aktif bertanya dan membuat cara berpikir menjadi lebih kritis dengan butki data yang diperoleh media berita TV baik digunakan dalam pembelajaran menulis teks eksplanasi.

b) Kemampuan Menulis Teks Eskplanasi

Berdasarkan analisis data hasil penelitian, diketahui bahwa kelas XI PN 1 mempunyai potensi awal yang kurang baik pada materi menulis teks eksplanasi. Hal tersebut diketahui melalui rata-rata nilai pretest atau hasil belajar awal siswa.

Perolehan nilai tersebut dianggap kurang baik namun hampir seluruh siswa paham mengenai teks ekslanasi, hanya saja tidak memahami strutur dan kaidah penulisannya. Nilai rata-rata sebelum pembelajaran tersebut menandakan bahwa siswa telah memiliki pengetahuan berkaitan dengan materi yang hendak dipelajari. Keadaan tersebut sesuai dengan pandangan Von Glaserfeld (Suparno, 1996) menyatakan bahwa anak sudah membawa "pengetahuan awal" dari lingkungan hidup mereka, pengetahuan awal 
yang mereka punya adalah untuk membangun pengetahuan selanjutnya.

Pada pembelajaran akhir siswa diberikan perlakuan dengan menggunakan media berita TV. Dengan hasil ratarata yang memuaskan karena adanya suatu peningkatan hasil belajar siswa. Hal ini sesuai dengan salah satu karateristik penelitian eksperimen yang dikemukan oleh Ruseffendi (2006: 55), bahwa equivalensi subjek dalam kelompok-kelompok yang berbeda perlu ada, agar bila ada hasil yang berbeda yang diperoleh oleh kelompok, itu bukan disebabkan karena tidak equivalennya kelompok-kelompok itu, tetapi karena adanya perlakuan.

Peningkatan kemampuan menulis siswa dipengaruhi oleh media pembelajaran yaitu dengan media berita TV. Hal tersebut sesuai dengan yang diungkapkan oleh Miarso (2004:458) bahwa media pembelajaran adalah segala sesuatu yang digunakan untuk menyalurkan pesan serta dapat merangsang pikiran, perasaan, perhatian, dan kemauan si belajar sehingga dapat mendorong terjadinya proses belajar.

c) Berpikir Kritis Siswa

Berpikir kritis siswa pada kelas XI PN 1 bertujuan untuk mengetahui tingkat pemahaman dan pola pikir belajar siswa terhadap materi menulis teks eksplanasi. Menurut Hidayati (2009:24) kemampuan berpikir kritis merupakan sesuatu yang paling esensial dalam pembelajaran bahasa. Oleh karena itu, bahasa sering disebut sebagai alat berpikir, walaupun kita lebih menyadarinya sebagai alat interaksi sosial.

Dari temuan di atas menjelaskan bahwa setelah melakukan proses pembelajaran dengan media berita TV kemampuan berpikir kritis siswa menjadi leboh baik daripada sebelum menggunakan media pembelajaran. Hal tersebut dapat didukung dengan hasil bservasi siswa pada awal pembelajaran dan akhir pembelajaran.

\section{KESIMPULAN}

Berdasarkan hasil analisis data dan pengujian hipotesis, maka penulis dapat menarik kesimpulan sebagai berikut.

1) Terdapat peningkatan berpikir kritis siswa dalam pembelajaran menulis teks eksplanasi dengan menggunakan media berita TV. Hal tersebut dapat dilihat dengan beberapa aspek penilai menulis teks eksplanasi yang berorientasi berpikir kritis. Selain itu hal lain didukung dengan hasil pembuatan peta konsep yang sibuat oleh siswa.

2) Terdapat peningkatan hasil belajar siswa dalam menulis teks eksplanasi dengan menggunakan media berita TV. Pembelajaran akhir setelah diberikan tratment lebih baik daripada pembelajaran awal.

3) Berita TV baik digunakan untuk meningkatkan berpikir kritis siswa dalam pembelajaran menulis teks eksplanasi. Hal tersebut dapat dibuktikan dari observasi siswa dengan melihat aktivitas sebelum pembelajaran dan setelah menggunakan media berita TV.

\section{DAFTAR PUSTAKA}

Alwasilah, (2007). Pokoknya menulis. Bandung: PT Kiblat Buku Utama.

Arsyad, Azhar. (2002). Media pembelajaran. Jakarta: PT Raja Grafindo Persada.

Arikunto, S. (2006). Prosedur penilitian suatu pendekatan praktis. Jakarta: PT. Rineka Cipta.

Arikunto, S. (2010). Dasar-dasar evaluasi pendidikan (edisi revisi). Jakarta: Bumi Aksara

Browne dan Keeley. (2015). Pemikiran kritis. Jakarta: PT. Indeks.

Chaer, Abdul. (2012). Bahasa jurnalistik. Jakarta: Rineka Cipta. 
Desmita. (2005). Psikologi perkembangan. Bandung: Remaja Rosdakarya.

Daryanto. (2010). Media pembelajaran. Yogyakarta: Gava Media.

Effendy, Onong Uchjana. (2000). Ilmu, Teori dan Filsafat Komunikasi. Bandung: PT. Citra Aditya Bakti.

Emilia, E. (2011). Pendekatan genrebased dalam pengajaran bahasa inggris: petunjuk untuk guru. Bandung: Rizqi Press.

Fisher, A. (2009). Berpikir kritis: sebuah pengantar. Jakarta: Erlangga.

Goldberg, C.M. (2011). Dari pada bete nulis aja!. Bandung: MMU.

Halim, Syaiful. (2015). Dasar-dasar Jurnalistik Televisi. Yogyakarta: Deepublish.

Hamdani. (2011). Strategi belajar mengajar. Bandung: CV. Pustaka Setia.

Hasnun, A. (2006). Pedoman menulis untuk siswa smp dan sma. Yogyakarta: CV Andi Offset.

Hidayati, P.P. (2009). Menulis esai dan pembelajaran. Bandung: Prisma Press Prodaktama.

Imran. (2014). Keuntungan tv sebagai media pembelajaran. Tersedia: http://ilmu-

pendidikan.net/pembelajaran/med ia-pembelajaran/keuntungan-tvsebagai-media-pembelajaran diakses Sabtu 9 April 2016.

Indrawan dan Yaniawati. (2014). Metode penelitian. Bandung: PT Refika Aditama.

Johnson, E. B. (2007). Contextual teaching and learning: menjadikan kegiatan belajar mengajar mengasyikan dan bermakna. Bandung: Mizan Learning Center.

Junaedi, Fajar. (2013). Jurnalisme penyiaran dan reportase televisi. Jakarta: Kencana.

Keraf, G. (2004). Argumentasi dan narasi. Jakarta: PT. Gramedia.
Kemendikbud. (2013). Buku guru bahasa indonesia wahana pengetahuan. Jakarta: Politeknik Negeri Media Kreatif.

Kosasih, E. (2014). Jenis-jenis teks. Bandung: Yrama Widya.

Kurniawan, dkk. (2009). Hrd: human resources development. Jakarta: PT. Gramedia.

Latuheru, JD. (1988). Media pembelajaran dalam proses belajar masa kini. Jakarta: P2LPTK .

Miarso, Y. (2004). Menyemai benih teknologi pendidikan. Jakarta: Kencana.

Molan, B. (2014). Logika ilmu dan seni berpikir kritis. Jakarta: PT. Indeks.

Mousir. (2014). Struktur, ciri, definisi, dan contoh teks eksplanasi. Tersedia:

http://www.kelasindonesia.com/2 015/05/struktur-ciri-definisi-dancontoh-teks-eksplanasi.html diakses Jumat 8 April 2016.

Mulyadi, Yadi. (2013). Bahasa indonesia untuk smp-mts kelas vii. Bandung: Yrama Widya.

Mulyana, A.Z. (2010). Rahasia menjadi guru hebat. Jakarta: Grasindo

Muslich, W. (2009). Ktsp pembelajaran berbasis kompetensi dan kontekstual. Jakarta: Bumi Aksara.

Munadi, Y. (2013). Media pembelajaran: suatu pendekatan baru. Jakarta: Gaung Pesada Press.

Nurgiantoro, B. (2010). Penilaian pembelajaran bahasa. Yogyakarta: BPFE-Yogyakarta.

Nurhayatin, T. (2009). Penilaian pembelajaran bahasa sastra indonesia berbasis kelas. Bandung: Prisma Press.

Oramahi, H. A. (2015). Jurnalistik televisi. Jakarta: Erlangga.

Pane, T.D. (2004). Speak out (panduang praktis dan jitu memasuki dunia broadcasting dan public spea- 
king). Jakarta: PT. Gramedia Pustaka Utama.

Pardiyono. (2007). Pasti bisa teaching genre based writing. Yogjakarta: Andi Offset.

Pramana, Andi. (2012). Analisis perbandingan trading volume activity dan abnormal return saham sebelum dan sesudah pemecahan saham (studi kasus pada perusahaan yang terdaftar di bursa efek indonesia periode 2007-2011). Semarang: Universitas Diponegoro.

Prihantini, Ainia. (2015). Master bahasa indonesia. Jogyakarta: PT Bentang Pustaka.

Putranto. (2012). Langkah-langkah Penggunaan Media. Tersedia: Error! Hyperlink reference not valid. diakses Sabtu 9 April 2016.

Rahman, Anita. (2016). Teknik dan Etik Profesi TV Presenter. Jakarta: Yayasan Pustaka Obor Indonesia.

Ruseffendi. (1998). Dasar-dasar penelitian pendidikan dan bidang noneksakta lainnya. Semarang: CV. IKIP Semarang

Sadiman, Arief S dkk. (2006). Media pendidikan pengertian, pengembangan dan pemanfaatannya. Jakarta: PT Raja Grafindo Persada.

Sakri, A. (1992). Bangun paragraf bahasa indonesia. Bandung: ITB.

Sardiman. (2006). Interaksi dan motivasi belajar mengajar. Jakarta: Raja Grafindo Persada.

Setiono, Kusdwiratri. (2009). Psikologi perkembangan. Bandung: Widya Padjajaran.

Sobandi. (2014). Bahasa indonesia untuk sma/ ma kelas xi. Jakarta: Erlangga.

Subana. H. M. (2011). Dasar-dasar penelitian ilmiah. Bandung: CV Pustaka Setia.

Sugiyono. (2010). Statistik untuk penelitian. Bandung: Alfabeta.
Sumarmo, U. (2010). Berpikir dan disposisis matematik: apa, mengapa, dan bagaimana dikembangkan pada peserta didik. Artikel. FPMIPA UPI.

Susanto, Hadi. (2013). Kemampuan berpikir kritis. Tersedia: https://bagawanabiyasa.wordpress.com/2013/05/02 /kemampuan-berpikir-kritis/ diakses Jumat 8 April 2016.

Sutisno, P.C.S. (1993). Pedoman praktis penulisan skenario televisi dan video. Jakarta: PT. Grasindo.

Syamsudin dan Damaianti. (2009). Metode penelitian pendidikan bahasa. Bandung: PT. Rosdakarya.

Syas, E.J. (2013). Fungsi media pembelajaran. Tersedia: http://ekajihadahsyas-pmt-iva.blogspot.co.id/ diakses Jumat 8 April 2016.

Tamrin, E. M. (2009). Solusi taktis un bahasa inggris sma. Jakarta: Media Pusindo.

Tarigan, H.G. (2008). Menulis sebagai suatu keterampilan berbahasa. Bandung: Angkasa Bandung.

Warwanto, dkk. (2009). Pendidikan religiositas:gagasan, isi dan pelaksanaannya. Yogyakarta: Kanisius (IKAPI).

Widyastuti, Sri Harti \& Nurhidayati. (2010). Pengembangan media pembelajaran bahasa jawa. Universitas Negeri Yogyakarta: Program Studi Bahasa Jawa.

Widjono. (2005). Bahasa indonesia. Jakarta: Grasindo.

Wikipedia. (2011). Pengertian berita. Tersedia: https://id.wikipedia.org/ wiki/Berita diakses kamis, 7 April 2016. 